\title{
Cytoreductive Surgery and Hyperthermic Intraperitoneal Chemotherapy for Peritoneal Metastasis from Breast Cancer: A Preliminary Report on 4 Cases
}

Jun-Hui Yu

Department of Peritoneal Cancer Surgery, Beijing Shijitan Hospital, Capital Medical University

Yu Feng

Beijing Shijitan Hospital, Capital Medical University

Xin-Bao Li

Beijing Shijitan Hospital, Capital Medical University

Cheng-Yan Zhang

Beijing Shijitan Hospiital, Capital Medical University

Feng Shi

Beijing Shijitan Hospital, Capital Medical University

\section{Song-Lin An}

Beijing Shijitan Hospital, Capital Medical University

\section{Gang Liu}

Beijing Shijitan Hospital, Capital Medical University

\section{Yan-Bin Zhang}

Beijing Shijitan Hospital, Capital Medical University

\section{Kai Zhang}

Beijing Shijitan Hospital, Capital Medical University

\section{Zhong-He Ji}

Beijing Shijitan Hospital, Capital Medical University

\section{Bing Li}

Beijing Shijitan Hospital, Capital Medical University

\section{Guo-Jun Yan}

Beijing Shijitan Hospital, Capital Medical University

\section{Yan-Ping Li}

Beijing Shijitan Hospital, Capital Medical University

\section{Yan Li ( $\square$ liyansd2@163.com )}

department of peritoneal cancer surgery, Beijing Shijitan Hospital affiliated to the captial medical university, Beijing, 100038,China 
Research

Keywords: Breast cancer, Cytoreductive surgery, Hyperthermic intraperitoneal chemotherapy, Peritoneal carcinomatosis

Posted Date: June 8th, 2020

DOI: https://doi.org/10.21203/rs.3.rs-33262/v1

License: (c) (i) This work is licensed under a Creative Commons Attribution 4.0 International License. Read Full License

Version of Record: A version of this preprint was published at Gland Surgery on April 1st, 2021. See the published version at https://doi.org/10.21037/gs-20-893. 


\section{Abstract}

Background: Breast cancer (BC) has been ranked as the first malignancy most common and the fifth in mortality rate among women in China. Peritoneal metastases from $\mathrm{BC}$ is a rare disease and no guideline or international consensus for it.

Objective: To summarise our experiences in cytoreductive surgery (CRS) and hyperthermic intraperitoneal chemotherapy (HIPEC) to treat breast cancer peritoneal carcinomatosis (BC PC).

Methods: 4 BC PC patients underwent CRS+HIPEC were enrolled in this study. The clinic-pathologic characteristics and overall survival (OS) were collected and analysed.

Result: The average age at CRS+HIPEC was 59.8 years. The average time of CRS+HIPEC was $8.8 \mathrm{~h}$. The median number of resected organ areas was 7. Overall survival from CRS+HIPEC were 31, 28, 16 and 52 months. There were no serious adverse events (SAEs) during the perioperative period.

Conclusions: The 4 cases provided evidence that integrated therapy with CRS+HIPEC may be a promising strategy to improve the outcome for BC PC patients.

\section{Background}

Breast cancer (BC) has been ranked as the first malignancy in incidence and the fifth mortality rate among women in China [1]. The most common metastasis sites of primary BC with invasive ductal carcinoma (IDC) include regional lymph nodes, lung, liver, bones, brain, and skin. BC with invasive lobular carcinoma (ILC) frequently affects bones, retroperitoneum, peritoneum, gynaecological organs, and gastrointestinal $(\mathrm{Gl})$ tract [2-3]. The five-year survival of $\mathrm{BC}$ has been increasing but the treatment of recurrent $B C$ is a challenge [4-5]. Especially peritoneal metastasis from $B C$ is a poorly defined entity [6]. Current literature provide scarce information on its management and no guideline or international consensus for it.

Here we report 4 BC PC cases with multiple therapeutic modalities, including cytoreductive surgery (CRS) and hyperthermic intraperitoneal chemotherapy (HIPEC) to determine the role of CRS + HIPEC in BC PC.

\section{Patients And Methods}

\section{Clinical information}

From January 2015 to March 2020, a total of 893 BC patients have underwent radical resection at Beijing Shijitan Hospital, 17 of which have progressive disease with PC. There are 4 BC PC patients who underwent CRS + HIPEC enrolled in this retrospective study. The diagnosis of BC PC is confirmed by pathology in all patients. 
The study design was approved by the Ethical Committee of the Beijing Shijitan Hospital. All patients were introduced to the detailed process of CRS + HIPEC and signed informed consent.

Inclusion criteria: 1) all BC PC patients were diagnosed by pathology; 2) Karnofsky performance status (KPS) score $\geq 60 ; 3$ ) the functions of cardiovascular, liver, kidney and lung could withstand the operation.

Exclusion criteria: 1) malignant tumors other than $\mathrm{BC}$; 2) major organ functions failure could not withstand operation. [7].

\section{CRS + HIPEC procedure}

All CRS + HIPEC were conducted by the same professional PC treatment team. Peritoneal cancer index $(\mathrm{PCl})$ was evaluated through the nature of ascites, tumor size and location after cutting the abdominal cavity [8] (Fig. 1A). Subsequently, according to the peritonectomy procedures by Sugarbaker, the curative or palliative resection, peritonectomy, lymphadenectomy to maximal CRS [9]. Completeness of cytoreduction (CC) was evaluated based on residual tumor size [10] (Fig. 1B). The HIPEC regimen consisted of docetaxel $120 \mathrm{mg}$ plus cisplatin $120 \mathrm{mg}$. The HIPEC was conducted through the open Colliseum technique. [11].Each drug was added to $3 \mathrm{~L}$ saline and heated to $43 \pm 0.5{ }^{\circ} \mathrm{C}$. The HIPEC time for each drug was 30 minutes and the flow rate was $400 \mathrm{ml} / \mathrm{min}$. Gastrointestinal tract reconstruction, abdominal drainage tube placement and tension reduction suture incision were performed after HIPEC[12].

\section{Study endpoint}

The primary endpoint was the overall survival from CRS + HIPEC. The secondary endpoint was the perioperative safety of CRS + HIPEC in BC PC.

\section{Definition}

Overall survival (OS) was defined as the day from CRS + HIPEC to the day of death or related with BC PC or the last follow-up.

The perioperative period was defined as 30 days after CRS + HIPEC[12].

\section{Follow-up}

1) Once three months within 2 years and once six months beyond 2 years after CRS + HIPEC; 2) Follow-up items included: physical examination, tumor markers, breast and gynaecological color Doppler ultrasound, chest and abdomen computed tomography (CT); 3) The last follow-up date was March 1 , 2020 , with the rate of $100 \%$.

\section{Results}




\section{Major clinicopathological characteristics}

All 4 patients were female. The average age was 59.8 (50-65) years at CRS + HIPEC. In terms of pathology, there were 1 case with ILC and 3 cases with IDC. Molecular typing of primary tumors of all 4 cases was Luminal B. The major clinicopathological characteristics of primary BC and metastasis PC were shown in Table 1. 
Table 1

Major clinicopathological characteristics of primary BC and metastasis PC

\begin{tabular}{|c|c|c|c|c|}
\hline Characteristics & Case 1 & Case 2 & Case 3 & Case 4 \\
\hline $\begin{array}{l}\text { Age at diagnosis of } \\
\text { breast cancer, years }\end{array}$ & 50 & 60 & 53 & 50 \\
\hline Gender & Female & Female & Female & Female \\
\hline $\begin{array}{l}\text { Breast tumor } \\
\text { localisation }\end{array}$ & Left & Right & Right & Left \\
\hline $\begin{array}{l}\text { Most extensively } \\
\text { performed breast } \\
\text { surgery }\end{array}$ & $\begin{array}{l}\text { Modified } \\
\text { radical } \\
\text { mastectomy }\end{array}$ & $\begin{array}{l}\text { Breast segment } \\
\text { resection }\end{array}$ & $\begin{array}{l}\text { Modified } \\
\text { radical } \\
\text { mastectomy }\end{array}$ & $\begin{array}{l}\text { Modified } \\
\text { radical } \\
\text { mastectomy }\end{array}$ \\
\hline $\begin{array}{l}\text { Breast tumor } \\
\text { histological subtype }\end{array}$ & $\mathrm{ILC}^{1}$ & $\mathrm{IDC}^{2}$ & $\mathrm{IDC}^{2}$ & $\mathrm{IDC}^{2}$ \\
\hline $\begin{array}{l}\text { Scarff-Bloom- } \\
\text { Richardson grade }\end{array}$ & प & प & II & प \\
\hline Tumor stage & $\mathrm{T} 2$ & T2 & $\mathrm{T} 2$ & $\mathrm{~T} 2$ \\
\hline Nodal stage & N2 & N2 & No & NO \\
\hline Metastasis & 0 & 1 & 0 & 1 \\
\hline TNM stage & Illa & IV & lla & IV \\
\hline $\begin{array}{l}\text { Estrogen receptor } \\
\text { (Primary } \\
\text { tumor/Metastasis } \\
\text { tumor) }\end{array}$ & $\begin{array}{l}\text { Positive / } \\
\text { Positive }\end{array}$ & Positive / Positive & $\begin{array}{l}\text { Positive / } \\
\text { Positive }\end{array}$ & $\begin{array}{l}\text { Positive / } \\
\text { Positive }\end{array}$ \\
\hline $\begin{array}{l}\text { Progesterone receptor } \\
\text { (Primary } \\
\text { tumor/Metastasis } \\
\text { tumor) }\end{array}$ & $\begin{array}{l}\text { Positive / } \\
\text { Positive }\end{array}$ & Positive / Negative & $\begin{array}{l}\text { Negative / } \\
\text { Negative }\end{array}$ & $\begin{array}{l}\text { Negative / } \\
\text { Positive }\end{array}$ \\
\hline $\begin{array}{l}\text { Her2/neu receptor } \\
\text { (Primary } \\
\text { tumor/Metastasis } \\
\text { tumor) }\end{array}$ & $\begin{array}{l}\text { Negative / } \\
\text { Negative }\end{array}$ & Positive / Positive & $\begin{array}{l}\text { Negative / } \\
\text { Negative }\end{array}$ & $\begin{array}{l}\text { Negative / } \\
\text { Negative }\end{array}$ \\
\hline $\begin{array}{l}\text { Ki-67 (Primary } \\
\text { tumor/Metastasis } \\
\text { tumor) (\%) }\end{array}$ & $20 / 30$ & $50 / 50$ & $25 / 50$ & $90 / 20$ \\
\hline $\begin{array}{l}\text { Molecular subtypes } \\
\text { (Primary tumor) }\end{array}$ & Luminal B & Luminal B & Luminal B & Luminal B \\
\hline Postoperative pathology & $\mathrm{ILC}^{1}$ & $\mathrm{IDC}^{2}$ & $\mathrm{IDC}^{2}$ & $\mathrm{IDC}^{2}$ \\
\hline $\begin{array}{l}\text { Age at diagnosis of } \\
\text { peritoneal metastases, } \\
\text { years }\end{array}$ & 64 & 60 & 65 & 50 \\
\hline
\end{tabular}




\begin{tabular}{|lllll|}
\hline Characteristics & Case 1 & Case 2 & Case 3 & Case 4 \\
\hline $\begin{array}{l}\text { Time between breast } \\
\text { cancer and peritoneal } \\
\text { metastases, months }\end{array}$ & 174 & 0 & 120 & 0 \\
\hline Clinical presentation & $\begin{array}{l}\text { Abdominal } \\
\text { distension }\end{array}$ & $\begin{array}{l}\text { Frequent urination, } \\
\text { constipation and } \\
\text { abdominal pain }\end{array}$ & $\begin{array}{l}\text { Abdominal } \\
\text { pain and } \\
\text { abdominal } \\
\text { distension }\end{array}$ & $\begin{array}{l}\text { Left breast } \\
\text { mass and } \\
\text { abdominal } \\
\text { distension }\end{array}$ \\
\hline $\begin{array}{l}\text { Diagnosis of peritoneal } \\
\text { metastasis }\end{array}$ & $\begin{array}{l}\text { Postoperative } \\
\text { pathology }\end{array}$ & $\begin{array}{l}\text { Postoperative } \\
\text { pathology }\end{array}$ & $\begin{array}{l}\text { Postoperative } \\
\text { pathology }\end{array}$ & Needle biopsy \\
\hline $\begin{array}{l}\text { 1. Invasive lobular carcinoma } \\
\text { 2. Invasive ductal carcinoma }\end{array}$ & & & \\
\hline
\end{tabular}

\section{Major characteristics of CRS + HIPEC}

The average time of CRS + HIPEC was $8.8 \mathrm{~h}$ (range: 7-10.6 h). The median number of resected organs was 7 (range: $5-9$ ). The average blood loss was $525 \mathrm{ml}$ (range: $400-800 \mathrm{ml}$ ). The average ascites volume was $3,625 \mathrm{ml}$ (range: $1,000-10,000 \mathrm{ml}$ ). In regard to HIPEC regimen, all 4 cases were with docetaxel $120 \mathrm{mg}$ plus cisplatin $120 \mathrm{mg}$. The average PCl was 29.5 (range: 21-39). The case 1 and case 2 reached to $C C 0$. The case 3 and case 4 only reached to CC 3. The major clinicopathological characteristics of CRS + HIPEC were showed in Table 2. 
Table 2

Major clinicopathological characteristics of CRS + HIPEC

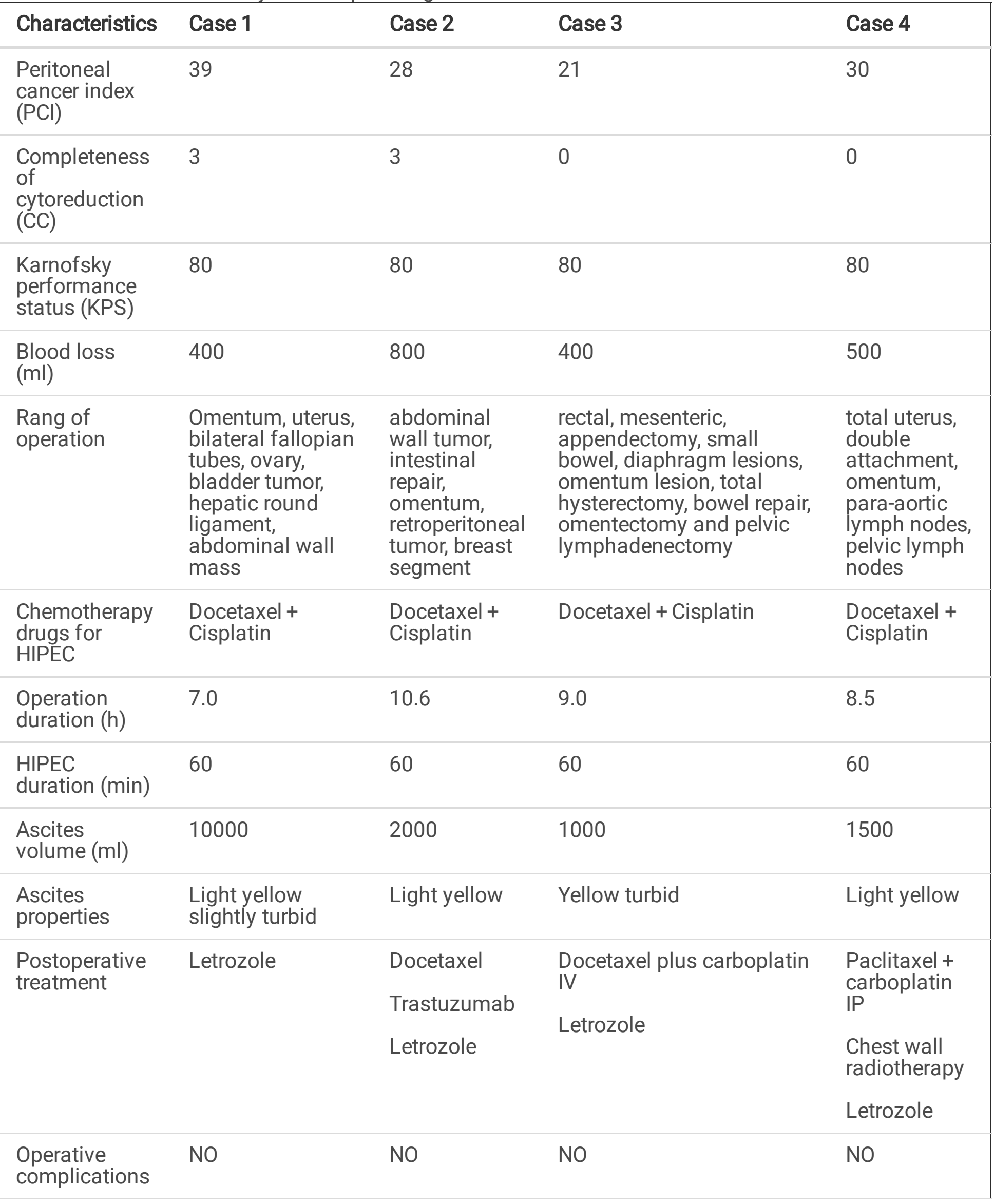




\begin{tabular}{|c|c|c|c|c|}
\hline Characteristics & Case 1 & Case 2 & Case 3 & Case 4 \\
\hline $\begin{array}{l}\text { The average } \\
\text { hospital stay } \\
\text { after CRS + } \\
\text { HIPEC (d) }\end{array}$ & 15 & 10 & 21 & 12 \\
\hline $\begin{array}{l}\text { Overall } \\
\text { survival from } \\
\text { diagnosis } \mathrm{BC} \\
\left(\mathrm{OS}_{1}\right) \text { (month) }\end{array}$ & 205 & 28 & 136 & 52 \\
\hline $\begin{array}{l}\text { Overall } \\
\text { survival from } \\
\text { CRS + HIPEC } \\
\left(\mathrm{OS}_{2}\right) \text { (month) }\end{array}$ & 31 & 28 & 16 & 52 \\
\hline
\end{tabular}

\section{OS and safety analysis}

All 4 patients were alive and overall survival from CRS + HIPEC were 31, 28, 16 and 52 months, respectively. Overall survival from diagnosis $B C$ was $205,28,136$ and 52 months, respectively. (Table 2)

There were no serious adverse events (SAEs) during the perioperative period.

\section{Discussion}

Our study demonstrates that patients with BC PC can benefit from CRS + HIPEC. CRS + HIPEC not only improves the quality of life but also extends overall survival. There are no SAEs during CRS + HIPEC perioperative period.

PC usually originated from gastrointestinal tumor and female gynaecological tumor. Typical metastasis sites of BC were bones, lungs, liver and brain. Many other sites had been described in the literature, including the peritoneal metastases [13], with $0.7 \%$ of the prevalence of peritoneal metastases [14]. The data about peritoneal and gastrointestinal metastases of $\mathrm{BC}$ was the lack in the literature.

ILC accounts for less than $10 \%$ of all BCs and ICD accounts for more than $90 \%$. However, the loss of Ecadherin expression on the surface of tumor cells in ILC patients leads to more diverse forms of metastasis. It prevents cell adhesion and promotes tumor cell migration[15]. Peritoneal metastasis can be diagnosed by CT or surgery. IDC patients account for only $3 \%$ while ILC patients account for $11 \%(P=$ 0.006). Regardless of IDC or ILC, PC is an important reason of morbidity and mortality[16].

In this study, there were 1 patient with ILC and 3 patients with IDC of the primary BC (Fig. 2-4). The metastasis tumor was the same as the primary tumor.

The prognosis of PC showed poor survival than other regional metastases from BC. The median survival time was 20.5 months from diagnosis of metastasis BC while the median survival of patients with BC PC was only 1.5 months [17]. Another study showed the OS was 5.8 months in patients with BC PC from the 
metastasis PC was diagnosed as compared to 22.6 months in patients with no metastasis PC. Patients with synchronous metastases have significantly better survival than those with metachronous metastases[18].

There were 2 cases with metachronous metastases and 2 cases with synchronous metastases in our study. The OS of the synchronous metastases' patients had reached 28 months and the longest OS of the metachronous metastases had reached 52 months to March 2020.

BC PC caused abdominal distension, abdominal pain or severe intestinal obstruction. And all patients in our study had at least one of the above symptoms. However, there were no effective treatments to relieve these symptoms and chronic malnutrition caused poor prognosis. The traditional treatment methods for BC PC were chemotherapy or radiotherapy and patients had poor survival. The treatment of BC PC in this study was chemotherapy combined with CRS + HIPEC. To achieve a radical CRS, the median number of resected organs were 7 and 2 patients reached $\mathrm{CC} 0$. The tolerance to hyperthermia was higher in normal tissue than the tumor tissue. HIPEC could prevent the adhesion postoperatively, as well as decrease the accelerative effect of healing on tumor cell entrapment by killing the granulocytes and monocytes. The synergistic anti-cancer effect could be dramatically increased at $43^{\circ} \mathrm{C}$. Hyperthermia could increase the response rates of cancer cells to HIPEC drugs, and the depth of HIPEC drugs into the tumor tissues. At last, loosening the adhesion of the intestine or ileostomy could relieve the intestinal obstruction. In our study, one case underwent loosening the adhesion of the intestine, and another underwent ileostomy, the abdominal distension or bowel obstruction of which relieved completely. All patients received adjuvant chemotherapy and endocrine therapy pre-and post-CRS + HIPEC, with 32 months of the average OS, which was better than literature.

Estrogen played an important role in the occurrence and prognosis of BC. The estrogen receptor (ER) was one of the important biomarkers to predict the prognosis of $\mathrm{BC}[19]$. $\mathrm{BC}$ patients with ER- and progesterone receptor (PR)- positive had a better prognosis [20]. Human epidermal growth factor receptor 2 (HER-2) regulates cell proliferation, growth, and survival. HER-2 was a transmembrane tyrosine kinase receptor[21-22]. BC patients with high levels Ki-67 usually have a poor prognosis due to Ki-67 was a nuclear proliferation marker[23]. In our study, two patients with synchronous BC PC, one with Ki-67 80$90 \%$ and another with HER-2 positive, maybe one of the reasons for the early peritoneal metastasis. The other two cases received standard adjuvant therapy after the primary lesion. All patients received tamoxifen treatment for 5 years and metastasis occurred after 5 years of discontinuation (all 4 cases had positive estrogen receptors). So it was important for hormone receptor-positive BC PC patients. At present, all the 4 patients had received letrozole orally after CRS + HIPEC and chemotherapy. No tumor progression occurred at the time of follow-up.

The average $\mathrm{PCl}$ was 29.5 , which heralded the difficulty of CRS. The average duration was $8.8 \mathrm{~h}$, the median number of resected organs was 7, the average blood loss was $525 \mathrm{ml}$ and the average ascites volume was $3,625 \mathrm{ml}$. While there were no SAEs during the perioperative period and the average hospital stay was $15 \mathrm{~d}$. The safety of CRS + HIPEC was accepted. It was important that a professional PC 
treatment team implemented standardised CRS + HIPEC. Otherwise, you maybe come to the opposite conclusion that CRS + HIPEC was not the treatment of choice [24]. This article provided new ideas and methods for the treatment of BC PC patients.

The disadvantage of this study was that the number of patients was too small to perform statistical analysis. The follow-up time was short. Therefore, these findings in this study required more confirmations from a large sample of evidence.

\section{Conclusions}

This paper reported 4 typical cases of BC PC successfully treated by a radical comprehensive treatments with CRS + HIPEC. These patients kept in good condition till now, with 32 months of mean overall survival since CRS + HIPEC. The 4 cases provided evidence that integrated therapy with CRS + HIPEC may be a promising strategy to improve the outcome for BC PC patients.

\section{List Of Abbreviations}




\begin{tabular}{|ll|}
\hline Abbreviations & Full name \\
\hline BC & Breast cancer \\
\hline CRS & Cytoreductive surgery \\
\hline HIPEC & Hyperthermic intraperitoneal chemotherapy \\
\hline PC & Peritoneal carcinomatosis \\
\hline BC PC & Breast cancer peritoneal carcinomatosis \\
\hline SAES & Serious adverse events \\
\hline IDC & Invasive ductal carcinoma \\
\hline ILC & Invasive lobular carcinoma \\
\hline GI & Gastrointestinal \\
\hline KPS & Karnofsky performance status \\
\hline ULN & Upper limit of normal \\
\hline PCl & Peritoneal cancer index \\
\hline CC & Completeness of cytoreduction \\
\hline OS & Overall survival \\
\hline CT & Computed tomography \\
\hline ER & Estrogen receptor \\
\hline PR & Progesterone receptor \\
\hline HER-2 & Human epidermal growth factor receptor 2 \\
\hline
\end{tabular}

\section{Declarations}

\section{Ethics approval and consent to participate}

Not applicable.

\section{Consent for publication}

Written informed consent was obtained from the 4 patients for publication of this article and accompanying images. A copy of these written consent is available for review by the Editor-in-Chief of this journal. 


\section{Availability of data and material}

The datasets used and analysed during the current study are available from the corresponding author on reasonable request.

\section{Competing interests}

The authors declare that they have no competing interests.

\section{Funding}

This work was supported by the Beijing Municipal Administration of Hospital Ascent Plan (DFL20180701); Beijing Municipal Grant for Medical Talents Group on Peritoneal Surface Oncology (2017400003235J007) (both to Yan Li).

\section{Authors' contributions}

Jun-hui Yu organised the patient's medical records and was the major contributor in writing the manuscript.

Yu Feng, Xin-bao Li and Yan-Ping Li collected the patient's medical records.

Cheng-Yan Zhang and Feng Shi collected the patient's pathological pictures.

Song-Lin An, Gang Liu, Yan-Bin Zhang, Kai Zhang, Zhong-He Ji, Bing Li and Guo-Jun Yan conducted the procedures of CRS + HIPEC.

Yan Li designed the project, monitored project progress, and contributed to data evaluation of the manuscript.

\section{Acknowledgement}

Not applicable.

\section{References}

1. Chen W, Zheng R, Baade PD, Zhang S, Zeng H, Bray F, Jemal A, Yu XQ, He J. Cancer statistics in China, 2015. CA Cancer J Clin. 2016; 66: 115-32.

2. Solomayer EF, Diel IJ, Meyberg GC, Gollan C, Bastert G. Metastatic breast cancer: clinical course, prognosis and therapy related to the first site of metastasis. Breast Cancer Res Treat. 2000; 59(3): 
271-8.

3. Arrangoiz R, Papavasiliou P, Dushkin H, Farma M. Case report and literature review: metastatic Iobular carcinoma of the breast an unusual presentation. Int J Surg Case Rep. 2011; 2(8): 301-5.

4. Ghoncheh $\mathrm{M}$, Pournamdar Z, Salehiniya $\mathrm{H}$. Incidence and mortality and epidemiology of breast cancer in the world. Asian Pac J Cancer Prev. 2016; 17(3): 43-6.

5. Kouloulias V, Triantopoulou S, Uzunoglou N, Pistevou-Gompaki K, Barich A, Zygogianni A, Kyrgias G, Kardamakis D, Pectasidis D, Kouvaris J, Greek Society of Hyperthermic Oncology. Hyperthermia is now included in the NCCN clinical practice guidelines for breast cancer recurrences: an analysis of existing data. Breast Care. 2015; 10(2): 109-16.

6. Saranovic D, Kovac JD, Knezevic S, Susnjar S, Stefanovic AD, Saranovic DS, Obradovic V, Masulovic D, Micev M, Pesko P. Invasive lobular breast cancer presenting an unusual metastatic pattern in the form of peritoneal and rectal metastases: a case report. J Breast Cancer. 2011; 14(3): 247-50.

7. Yang XJ, Huang CQ, Suo T, Mei LJ, Yang GL, Cheng FL, Zhou YF, Xiong B, Yonemura Y, Li Y. Cytoreductive surgery and hyperthermic intraperitoneal chemotherapy improves survival of patients with peritoneal carcinomatosis from gastric cancer: final results of a phase III randomized clinical trial. Ann Surg Oncol. 2011; 18(6): 1575-81.

8. Jacquet $\mathrm{P}$, Sugarbaker $\mathrm{PH}$. Clinical research methodologies in diagnosis and staging of patients with peritoneal carcinomatosis. Cancer Treat Res. 1996; 82: 359-74.

9. Sugarbaker PH. Peritonectomy procedures. Ann Surg. 1995; 221(1): 29-42.

10. Sugarbaker $\mathrm{PH}$. Cytoreductive surgery and peri-operative intraperitoneal chemotherapy as a curative approach to pseudomyxoma peritonei syndrome. Eur J Surg Oncol. 2001; 27(3): 239-43.

11. Li XB, Peng KW, Ji Zh, Yu Y, Liu G, Li Y. Prevention of Venous Thromboembolism After Cytoreductive Surgery and Hyperthermic Intraperitoneal Chemotherapy: Development of a Physiotherapy Program. Clin Appl Thromb Hemost. 2019; 25:1076029619890415.

12. Li XB, Ma R, Ji ZH, Lin YL, Zhang J, Yang ZR, Chen LF, Yan FC, Li Y. Perioperative safety after cytoreductive surgery plus hyperthermic intraperitoneal chemotherapy for pseudomyxoma peritonei from appendiceal origin: Experience on 254 patients from a single center. Eur J Surg Oncol. 2020; 46(4 Pt A): 600-6.

13. Pasqual EM, Bertozzi S, Londero AP, Brandolin D, Mariuzzi L, De Pellegrin A, Bacchetti S, Zoratti L, Petri R, Della Bianca C, Snidero D, Terrosu G, Uzzau A, Risaliti A, Di Loreto C, Pizzolitto S, Zilli M, de Manzoni G. Microscopic peritoneal carcinomatosis in gastric cancer: prevalence, prognosis and predictive factors. Oncol Lett. 2018; 15(1): 710-6.

14. Bertozzi S, Londero AP, Cedolini C, Uzzau A, Seriau L, Bernardi S, Bacchetti S, Pasqual EM, Risaliti A. Prevalence, risk factors, and prognosis of peritoneal metastasis from breast cancer. Springerplus. 2015; 4(1): 688.

15. Ciriello G, Gatza ML, Beck AH, Wilkerson MD, Rhie SK, Pastore A, Zhang H, McLellan M, Yau C, Kandoth C, Bowlby R, Shen H, Hayat S, Fieldhouse R, Lester SC, Tse G, Factor RE, Collins LC, Allison KH, Chen YY, Jensen K, Johnson NB, Oesterreich S, Mills GB, Cherniack AD, Robertson G, Benz C, 
Sander C, Laird PW, Hoadley KA, King TA, Perou CM. Comprehensive molecular portraits of invasive lobular breast cancer. Cell. 2015; 163(2): 506-19.

16. Inoue M, Nakagomi H, Nakada H, Furuya K, Ikegame K, Watanabe H, Omata M, Oyama T. Specific sites of metastases in invasive lobular carcinoma: a retrospective cohort study of metastatic breast cancer. Breast Cancer. 2017; 24(5): 667-72.

17. Tuthill M, Pell R, Guiliani R, Lim A, Gudi M, Contractor KB, Lewis JS, Coombes RC, Stebbing J. Peritoneal disease in breast cancer: a specific entity with an extremely poor prognosis. Eur $\mathrm{J}$ Cancer. 2009; 45(12): 2146-9.

18. Flanagan M, Solon J, Chang KH, Deady S, Moran B, Cahill R, Shields C, Mulsow J. Peritoneal metastases from extra-abdominal cancer - a population-based study. Eur J Surg Oncol. 2018; 44(11): 1811-7.

19. Fragomeni S M, Sciallis A, Jeruss J S. Molecular subtypes and local-regional control of breast cancer. Surg Oncol Clin N Am. 2018; 27(1): 95-120.

20. Oudanonh T, Nabi H, Ennour-Idrissi K, Lemieux J, Diorio C. Progesterone receptor status modifies the association between body mass index and prognosis in women diagnosed with estrogen receptor positive breast cancer. Int J Cancer. 2020; 146(10): 2736-45.

21. Kim MH, Kim GM, Kim JH, Kim JY, Park HS, Park S, Cho YU, Park BW, Kim SI, Sohn J. Intermediate HER2 expression is associated with poor prognosis in estrogen receptor-positive breast cancer patients aged 55 years and older. Breast Cancer Res Treat. 2020; 179(3): 687-97.

22. Harbeck N, Gnant M. Breast cancer. Lancet. 2017; 389(10074): 1134-50.

23. Dumanskiy YV, Bondar OV, Stoliarchuk EA. The Ki-67 marker for assessing the effectiveness of systemic or regional neoadjuvant polychemotherapy in patients with locally advanced breast cancer. Exp Oncol. 2019; 41(2): 176-8.

24. Beniey M. Peritoneal metastases from breast cancer: a scoping review. Cureus. 2019; 11(8): e5367.

\section{Figures}


A

\section{Peritoneal Cancer Index (PCI)}

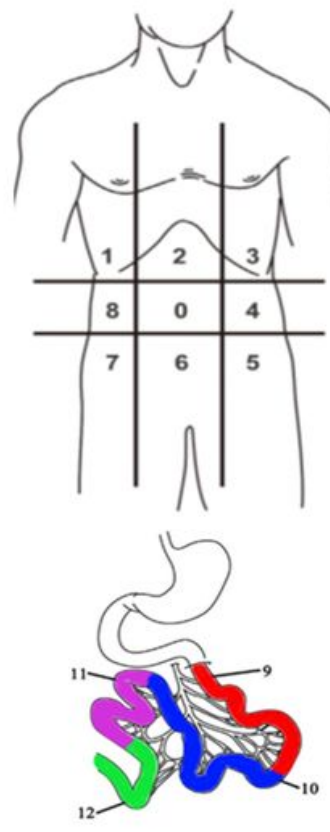

Lesion Size Score

LS-0 No tumor seen

LS-1 Tumor up to $0.5 \mathrm{~cm}$

LS-2 Tumor up to $5.0 \mathrm{~cm}$

LS-2 Tumor $>5.0 \mathrm{~cm}$

$\underline{\text { Regions }}$

0 Central

1 Right Upper

2 Epigastrium

3 Left Upper

4 Left Flank

5 Left Lower

6 Pelvis

7 Right Lower

8 Right Flank

9 Upper Jejunum

10 Lower Jejunum

11 Upper Ileum

12 Lower Ileum

\section{PCI} or confluence

\section{B}

Completeness of Cytoreduction (CC)

CC-0

No disease

CC-1

$== \pm=30$

Present to $0.25 \mathrm{~cm}$

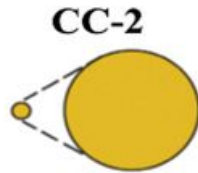

$0.25 \mathrm{~cm}$ to $2.5 \mathrm{~cm}$

$>2.5 \mathrm{~cm}$

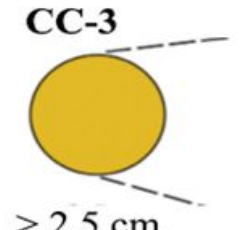

Figure 1

Peritoneal cancer index score (A) and completeness of cytoreduction score (B).
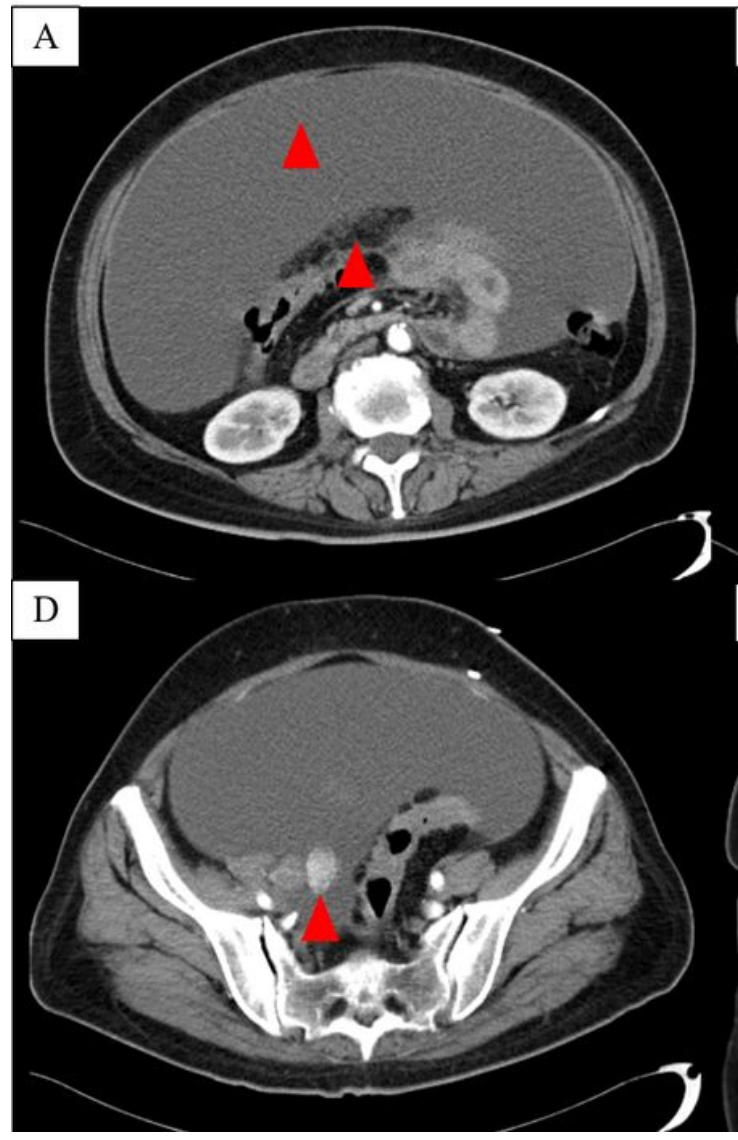

\section{$\underline{\text { Lesion Size }}$}

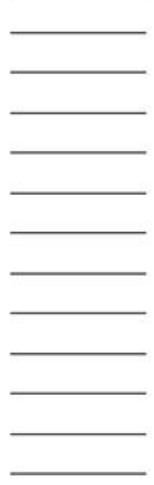




\section{Figure 2}

Preoperative image examination. A: Massive ascites and omentum contraction; B: Small intestine contraction; C: Peritoneal thickening; D: Pelvic tumor with contrast enhancement; E: Coronal showed Massive ascites; omentum contraction and small intestine contraction; F: Total gastrointestinal angiography showed the gathered small intestine.

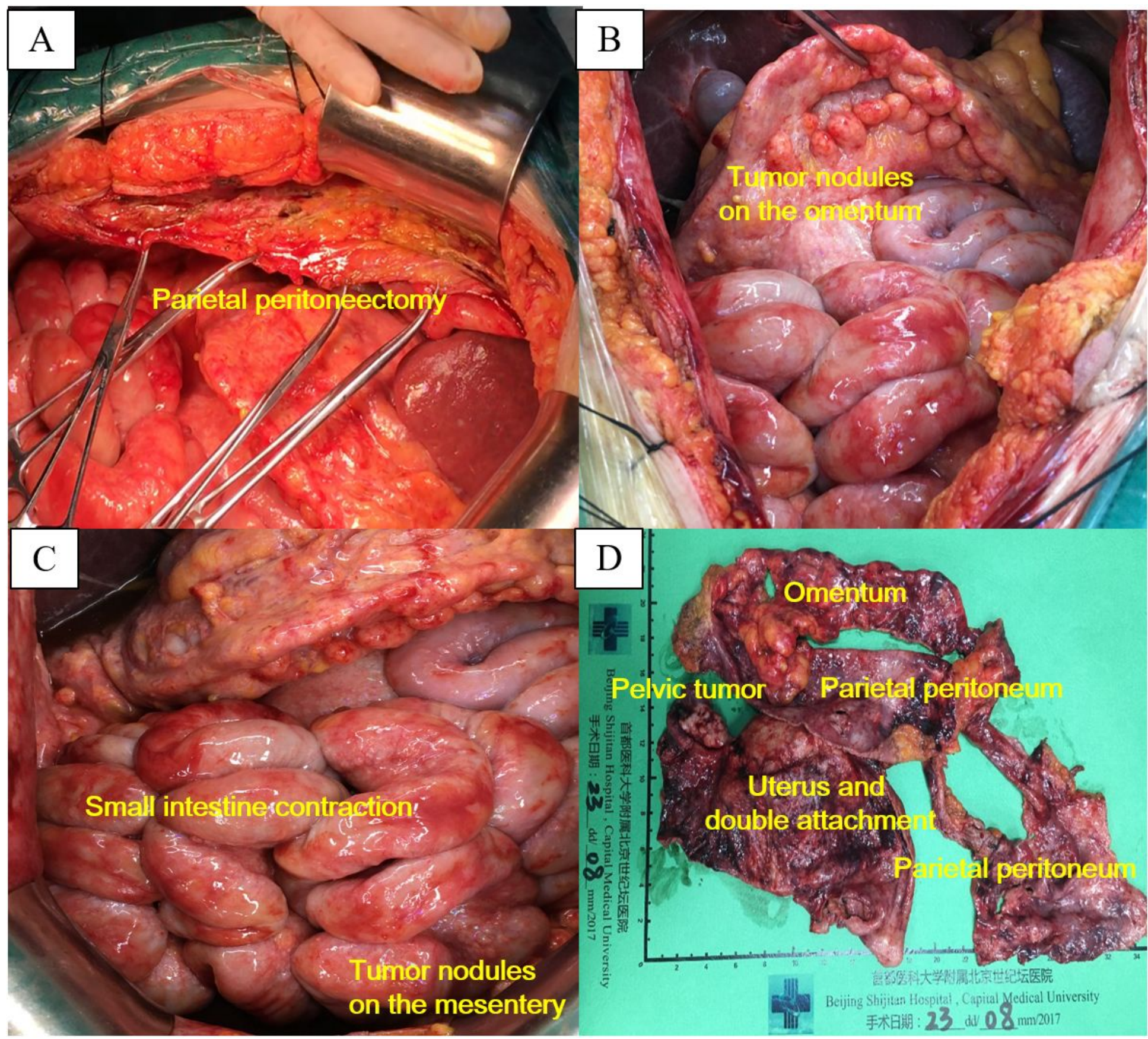

\section{Figure 3}

CRS intraoperative and postoperative specimens. A: Omentum contraction; B: Tumor nodules on the omentum; C: Small intestine contraction and tumor nodules on the mesentery; D: Postoperative specimens. 


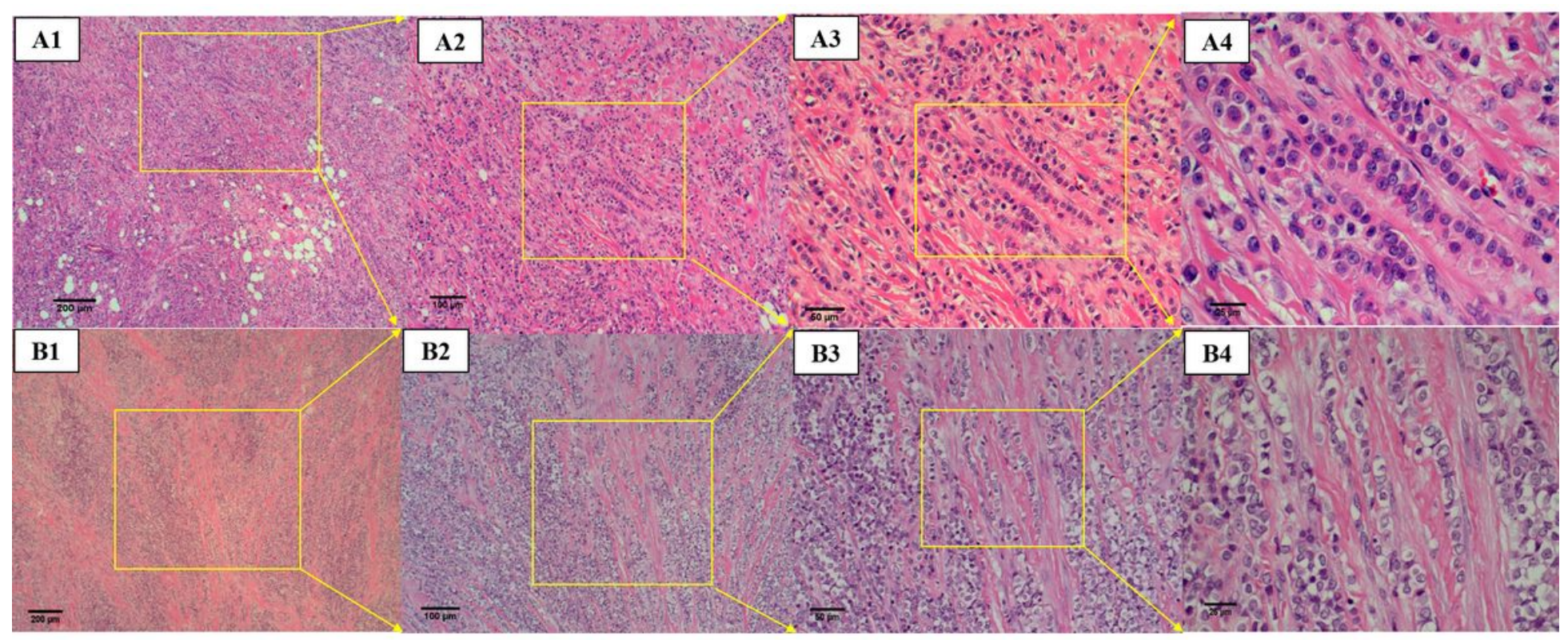

Figure 4

Pathological classification of primary (A1 - A4) and metastasis (B1 - B4) breast tumors (hematoxylineosin staining). A1: Invasive lobular carcinoma of the breast; A2: Tumor cells have poor adhesion and scattered in a single or single row of infiltrating interstitium; A3: Tumor cells infiltrate the stroma in a single row and forming a linear structure; A4: Tumor cells have smaller but the same size. Some cytoplasm contains eosinophilic globules and the nucleus is eccentric, round, small nucleolus and pathological mitosis are rare. B1: Invasive lobular carcinoma metastasises to the abdominal cavity and infiltrates into the peritoneal fibrous connectives; B2: Tumor cells have poor adhesion, diffuse, scattered in a single or single row of infiltrating interstitium; B3: Tumor cells infiltrate the stroma in a single row and forming a linear structure; B4: Tumor cells have the same size, nuclear round, small nucleoli are common and pathological mitosis is rare. The magnification of the pictures of the two-line from the left to right are $\times 50, \times 100, \times 200$ and $\times 400$, respectively. 